УдК 330.3:338.2

\title{
ІННОВАЦІЇ ЯК СКЛАДОВА СТРАТЕГІЇ УПРАВЛІННЯ КОНКУРЕНТОСПРОМОЖНІСТЮ СУБ'ЄКТА ГОСПОДАРЮВАННЯ
}

\section{INNOVATION AS A COMPONENT OF AN ENTERPRISE'S COMPETITIVENESS MANAGEMENT STRATEGY}

\author{
Бреус Світлана Василівна \\ доктор економічних наук, професор, \\ Київський національний університет технологій та дизайну \\ ORCID: https://orcid.org/0000-0003-0624-0219 \\ Бондар Анна Леонідівна \\ магістр. \\ Київський національний університет технологій та дизайну \\ ORCID: https://orcid.org/0000-0003-2497-5470 \\ Breus Svitlana, Bondar Anna \\ Kyiv National University of Technologies and Design
}

\begin{abstract}
Стаття присвячена дослідженню теоретико-методичних аспектів інноваційного розвитку суб'єкта господарювання у контексті визначення ролі та значення інновацій як складової стратегії управління його конкурентоспроможністю. Систематизовано, узагальнено та згруповано концептуальні підходи до управління конкурентоспроможністю суб'єкта господарювання. Наведено основні принципи формування стратегій управління конкурентоспроможністю суб'єкта господарювання, розроблення яких передбачає визначення та срормулювання стратегічних цілей. Розглянуто основні завдання, що вирішуються у процесі розроблення стратегій конкурентоспроможності з використанням інноваційної складової. Здійснено систематизацію підходів до фрормування та реалізації стратегії управління конкурентоспроможністю суб'єкта господарювання з урахуванням реалізації інноваційної складової.
\end{abstract}

Ключові слова: інновації, інноваційний розвиток, суб'єкт господарювання, стратегія, конкурентоспроможність, управління конкурентоспроможністю.

Статья посвящена исследованию теоретико-методических аспектов инновационного развития субъекта хозяйствования в контексте определения роли и значения инноваций как составляющей стратегии управления его конкурентоспособностью. Систематизированы, обобщены и сгруппированы концептуальные подходы к управлению конкурентоспособностью субъекта хозяйствования. Приведены основные принципы фрормирования стратегий управления конкурентоспособностью субъекта хозяйствования, разработка которых предусматривает определение и формулирование стратегических целей. Рассмотрены основные задачи, которые решаются в процессе разработки стратегий конкурентоспособности с использованием инновационной составляющей. Осуществлена систематизация подходов к фрормированию и реализации стратегии управления конкурентоспособностью субъекта хозяйствования с учетом реализации инновационной составляющей.

Ключевые слова: инновации, инновационное развитие, субъект хозяйствования, стратегия, конкурентоспособность, управление конкурентоспособностью.

The article is devoted to the research of theoretical and methodological aspects of innovative development of the business enterprise in the context of determining the role and importance of innovation as part of the strategy of managing the competitiveness of the business enterprise. The essence and characteristics of innovations as an economic category are studied. Emphasis is placed on the contradictions in the innovative development of the state, which is that Ukraine has significant innovation potential, but the presence of imperfect existing governance mechanisms and economic structures does not contribute to the use of existing innovation potential in sufficient quantities. Conceptual approaches to managing the competitiveness of an economic enterprise are systematized, generalized and grouped. The basic principles of formation of strategies of management of competitiveness of the economic entity are resulted and their characteristic features are considered. Emphasis is placed on the fact that the deve- 
lopment of strategies for managing the competitiveness of the enterprise involves defining and formulating strategic goals that serve as a starting point for selecting and developing an adequate strategy and are determined along with analyzing the internal environment of the entity in shaping its competitive behavior. market. It is established that special attention should be paid to assessing the innovative capabilities of the business entity to develop certain types of innovations. The main tasks that are solved in the process of developing competitiveness strategies using the innovation component are considered. The systematization of approaches to the formation and implementation of the strategy of managing the competitiveness of the business enterprise, taking into account the implementation of the innovation component. Emphasis is placed on the fact that in modern conditions there is no single model of strategy for managing the competitiveness of the enterprise, nor a universal approach to developing such a strategy. It is stated that the choice of adequate to modern conditions strategy for managing the competitiveness of the business enterprise depends largely on the available experience of its innovative activities and opportunities for practical use of the results of such activities.

Keywords: innovations, innovative development, business enterprise, strategy, competitiveness, competitiveness management.

Постановка проблеми. В сучасних умовах розвитку економіки України актуалізується доцільність здійснення ефективного управління конкурентоспроможністю суб'єкта господарювання 3 урахуванням інноваційної складової стратегії такого управління як важливого чинника забезпечення досягнення цілей та завдань з використанням ресурсів різних видів як важливого чинника, що справляє вплив на підвищення його конкурентоспроможності.

Здійснення такого управління з урахуванням сучасного рівня конкуренції та швидкості технологічних змін інновацій є важливою передумовою економічного зростання та розвитку як суб'єкта господарювання, так і промисловості й держави в цілому. Завдяки реалізації зазначеного підвищується ефективність виробничої діяльності суб'єкта господарювання у результаті підвищення його конкурентоспроможності, що сприятиме його на інноваційний шлях розвитку.

Аналіз останніх досліджень і публікацій. Основні аспекти інноваційного розвитку суб'єктів господарювання досить змістовно здійснено обґрунтування у контексті дослідження теоретико-методичних засад розроблення та реалізації інноваційної політики, зв'язку інновацій, стратегій управління інноваційною діяльністю з макроекономічним розвитком в працях великої кількості як іноземних, так і вітчизняних учених, зокрема таких як: А. Дука [1], С. Ілляшенко [2], Й. Шумпетер [3], М. Туган-Барановський [4], М. Кондратьєв [5].

Виділення невирішених раніше частин загальної проблеми. Проте, незважаючи на значний наукових доробок авторів за тематикою дослідження, слід зазначити, що детальнішого розгляду потребують питання, пов'язані з дослідженням інновацій як складової стратегії управління конкурентоспроможністю суб'єкта господарювання.
Формулювання цілей статті (постановка завдання). Мета статті полягає у дослідженні теоретико-методичних аспектів розроблення стратегії управління конкурентоспроможністю суб'єкта господарювання з урахуванням інноваційної складової такого управління.

Виклад основного матеріалу дослідження. Інновації та нововведення традиційно $€$ напрямом науково-технічного прогресу (його високотехнологічна складова) та процесом, пов'язаним із впровадженням досліджень й розробок у практику господарювання. Ссрера інновацій обширна, включає не тільки практичне використання науковотехнічних розробок та винаходів, а й зміни в продукції, процесах, маркетингу та організації. Інновація виступає як явний чинник змін у результаті діяльності, яка вбудована в новий або вдосконалений продукт, технологічні процеси, нові послуги та нові підходи до задоволення суспільних потреб [1, с. 67].

Сукупність процесів та явищ, які відбуваються на підприємствах різних секторів економіки розподіляють на групи: традиційні та інноваційні. Традиційні процеси та явища характеризують ефрективне фрункціонування національної економіки, промисловості, суб'єктів господарювання та їх інноваційний розвиток на якісно новому рівні. Розвиток та інтенсифрікація сучасного виробництва має базуватися насамперед на нових рішеннях у техніці та технологіях, організаційних фрормах та методах господарювання. Підготовка, прийняття та реалізація таких рішень $€$ змістом інноваційних процесів [2, с. 116].

Вперше термін «інновації» як категорія був використаний Й. Шумпетером [3] проте зміст та характеристика цього явища розглядалися ще його попередниками: М. Туган-Барановським [4] та М. Кондратьєвим [5].

Й. Шумпетер досліджував інновації як процеси, а не кінцевий продукт, розглядав як нову 
науково-організаційну комбінацію виробничих чинників, втілення результатів наукових досягнень у нових технологіях чи видах продукції й визначав таку інноваційну «тріаду»: «винахід-інновація-дифузія», яка пізніше була перетворена в інноваційний ланцюг: «науково-дослідні та дослідно-конструкторські роботи (НДДКР) - винахід - інноваційна дифузія - економічне зростання» [3].

Інновації $\epsilon$ винятково важливою економічною категорією, однак слід зазначити, що сьогодні відсутнє єдине визначення цього поняття. Термін «інновація» походить від англійського слова «innovation», що в перекладі означає «введення новацій». В наукових публікаціях як іноземних, так і вітчизняних авторів терміни «нововведення», «новація», «інноваційний процес», «новаторство» переважно розглядаються в якості синонімів [6].

Відповідно до Закону України «Про інноваційну діяльність» [7] інновації - це «новостворені (застосовані) і (або) вдосконалені конкурентоздатні технології, продукція або послуги, а також організаційно-технічні рішення виробничого, адміністративного, комерційного або іншого характеру, що істотно поліпшують структуру та якість виробництва і (або) соціальної ссрери».

За сучасних реалій у сорері інноваційного розвитку економіки України на всіх рівнях управління наявна суттєва суперечність, яка полягає в тому, що Україна має значний інноваційний потенціал, однак наявність недосконалих існуючих механізмів управління й економічних структур не сприяє використанню його в достатніх обсягах на належному рівні.

Однак, зважаючи на те, що сучасна світова економіка все більше набуває ознак інноваційної, підвищення конкурентоспроможності суб'єктів господарювання можливе не лише за рахунок використання інновацій, але й удосконалення організаційно-економічного механізму управління ними у результаті розроблення й реалізації адекватних сучасним умовам стратегій.

Реалізація зазначеного сприяє забезпеченню успіху в умовах фрункціонування суб'єктів господарювання у конкурентному середовищі, нівелювати, або принаймні, знизити ризики в їх діяльності. Таким чином, в сучасних умовах розвитку економіки України актуальним напрямом дослідження підвищення рівня управління інноваціями доцільним вбачається вважати їх впровадження в контексті розвитку конкурентоспроможності суб'єктів господарювання [8, с. 206].

Концептуальні підходи до управління конкурентоспроможністю суб'єкта господарювання наведені на рис. 1.

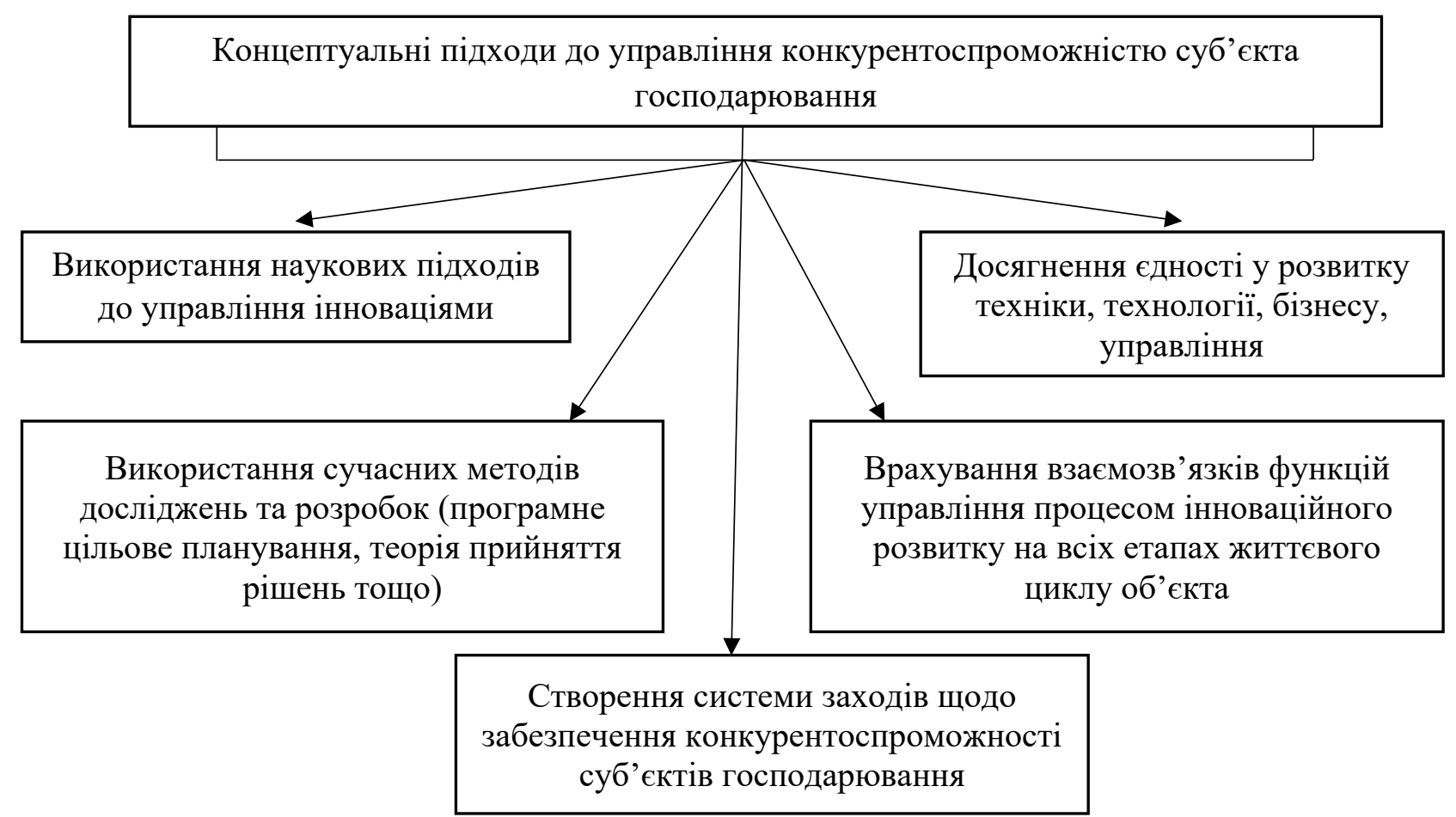

Рис. 1. Концептуальні підходи до управління конкурентоспроможністю суб'єкта господарювання

Джерело: систематизовано, узагальнено та згруповано за даними [9, с. 56] 
Істотна відмінність інноваційних підприємств полягає в тому, що створення в них інновацій $€$ різновидом бізнесу, тоді як у більшості організацій - це фрункція, частина загальної діяльності підприємства, при цьому, суб'єкт господарювання, що вступив на інноваційний шлях розвитку, має фрункціонувати у відповідності з принципами, основні з яких наведені у табл. 1 [10, с. 33]. Ці принципи за своїм змістом можна вважати принципами формування стратегій конкурентоспроможності суб'єкта господарювання.

Розроблення стратегій управління конкурентоспроможністю суб'єкта господарювання передбачає визначення та формулювання стратегічних цілей в межах оцінювання інноваційного розвитку. Ці цілі слугують в якості відправної точки для вибору та розроблення адекватної стратегії та визначаються наряду 3 аналізуванням внутрішнього середовища суб'єкта господарювання при фрормуванні його конкурентної поведінки на ринку. При цьому, особлива увага приділяється оцінюванню його можливостей щодо розроблення окремих видів інновацій.

Таким чином, можна стверджувати, що метою оцінювання ефрективності інновацій у конкурентоспроможному розвитку підприємства $€$ комплексне аналізування ефрективності інновацій та їх впливу на основні показники діяльності суб'єкта господарювання, визначення доцільності та оптимального впровадження нововведень, своєчасного впровадження інновацій. коригування інноваційних проєктів та підтримка стратегічних інновацій- них рішень. Таким чином, активізація інноваційного розвитку суб'єкта господарювання має бути поєднана [11]:

- 3 оновленням основних засобів, які мають стати основним джерелом збільшення обсягів виробництва та створення умов для виробництва вітчизняної продукції на рівні найкращих світових стандартів;

- із збереженням ресурсів, що, у кінцевому підсумку, призводить до значного зниження матеріальних витрат на одиницю продукції;

- із соціальною спрямованістю, за якої самі люди, якість та безпека їхнього життя повинні гарантувати реалізацію пріоритетів інноваційного розвитку.

Загалом інновації на підприємстві є предметом управлінського впливу, тому ефрективне управління ними вважається за доцільне розглядати як забезпечення досягнення цілей та завдань підвищення рівня конкурентоспроможності за рахунок використання ресурсів, інтелекту, ідей та мотивів поведінки працівників, що знаходить відображення у відповідних стратегіях. Результатом інноваційної діяльності суб'єкта господарювання має бути підвищення фрінансово-економічних показників; збільшення обсягів виробництва та реалізації продукції; розширення асортименту продукції; поширення присутності та існуючих ринках збуту продукції чи виходу на нові тощо.

В цілому, слід зазначити, що ні єдиної моделі стратегії управління конкурентоспроможністю суб'єкта господарювання, ні універсального підходу до ії розроблення, не

\section{Принципи формування стратегій управління конкурентоспроможністю}

Таблиця 1

\section{суб'єкта господарювання}

\begin{tabular}{|c|c|}
\hline Принципи & Сутність принципів \\
\hline 1. Адаптивності & $\begin{array}{l}\text { Полягає в прагненні до підтримання певного балансу зовнішніх та } \\
\text { внутрішніх можливостей розвитку: внутрішніх спонукальних мотивів } \\
\text { діяльності господарюючого суб'єкта і зовнішніх, що генеруються } \\
\text { ринковим середовищем }\end{array}$ \\
\hline 2. Динамічності & $\begin{array}{l}\text { Являє собою динамічне приведення у відповідність цілей і спонукальних } \\
\text { мотивів (стимулів) діяльності підприємства (включаючи його власників, } \\
\text { менеджерів, фахівців, працівників) }\end{array}$ \\
\hline 3. Самоорганізації & $\begin{array}{l}\text { Передбачає самостійне забезпечення підтримки умов фрункціонування, } \\
\text { тобто самопідтримання обміну ресурсами (інформаційними, } \\
\text { матеріальними, фрінансовими) між елементами виробничо-збутової } \\
\text { системи підприємства, а також між підприємством і зовнішнім } \\
\text { середовищем }\end{array}$ \\
\hline 4. Саморегуляції & $\begin{array}{l}\text { Полягає в коректуванні системи управління виробничо-збутовою } \\
\text { діяльністю підприємства відповідно до змін умов фуункціонування }\end{array}$ \\
\hline 5. Саморозвитку & $\begin{array}{l}\text { Передбачає самостійне забезпечення умов тривалого виживання і } \\
\text { розвитку підприємства (відповідно до його місії і прийнятої мотивації } \\
\text { діяльності) }\end{array}$ \\
\hline
\end{tabular}

Джерело: систематизовано, узагальнено та згруповано за даними [10, с. 33] 
існує. Ефективність інноваційного процесу [6; 12-13] певною мірою залежить від того, наскільки стратегічна мета може бути досягнута у разі розроблення та реалізації стратегії управління конкурентоспроможністю суб'єкта господарювання 3 урахуванням інноваційної складової, що загалом має сприяти збільшенню ролі такого управління.

Висновки. За результатом узагальнення вищезазначеного вважається за доцільне констатувати, що у процесі еволюції теорії та практики інноваційного розвитку суб'єктів господарювання та управління їх конкурентоспроможністю розроблено концептуальні підходи, сорормовано принципи й загалом створено широкий арсенал інструментів для вибору стратегій такого управління. Це з одного боку, спрощує процес їх фрормування та вибору, а 3 іншого - може призвести до його ускладнення, адже не завжди досягнення високого рівня інноваційного розвитку суб'єктів господарювання можливе за рахунок використання традиційних підходів до управління їх конкурентоспроможністю, що зумовлене значною мірою відсутністю єдиної моделі стратегії такого управління. При цьому, вибір адекватної сучасним умовам стратегії управління конкурентоспроможністю суб'єкта господарювання залежить значною мірою від наявного досвіду його інноваційної діяльності та можливостей практичного використання її результатів.

Перспективи подальших розвідок полягають у проведенні ґрунтовних досліджень щодо фрормування універсального підходу до управління конкурентоспроможністю суб'єкта господарювання 3 подальшим розробленням моделі стратегії такого управління на основі інноваційної складової.

\section{СПИСОК ВИКОРИСТАНИХ ДЖЕРЕЛ:}

1. Дука А.П. Теорія та практика інвестиційної діяльності : навч. посіб. Київ : Каравела, 2008. 432 с.

2. Ілляшенко С.М. Управління інноваційним розвитком: проблеми, концепції, методи : навч. посіб. для студ. вищих навч. закл. Суми : Університетська книга, 2003. 278 с.

3. Шумпетер Й. Теория экономического развития: Исследование предпринимательской прибыли, капитала, кредита, процента и цикла конъюнктуры. Москва : Прогресс, 1982. 456 с.

4. Туган-Барановський М.І. Політична економія. Курс популярний. Київ : Наукова думка, 1994. 264 с.

5. Кондратьев Н.Д. Проблемы экономической динамики. Москва : Экономика, 1989. 525 с.

6. Бреус С.В., Бондар А.Л. Управління інноваціями у контексті підвищення конкурентоспроможності суб'єкта господарювання. The VIII International Science Conference «Theoretical foundations of modern science and practice», November 08-10, Lisbon, Portugal. 2021. 277 p. P. 122-126.

7. Про інноваційну діяльність. Верховна Рада України. Закон від 04.07.2002. Документ 40-IV. Редакція від 05.12.2012, підстава 5460-VI. URL: https://zakon.rada.gov.ua/laws/show/40-15\#Text

8. Пересада А.А., Смірнова О.О., Онікієнко С.В., Ляхова О.О. Інвестування : навч.-метод. посіб. для самост. вивч. дисц. Київ : КНЕУ, 2015. 251 с.

9. Кухта П.В., Антонюк Є.В. Аналіз стану фрінансового забезпечення інноваційної діяльності в Україні: сучасний стан та особливості зростання. Вчені записки Університету «КРОК». 2015. Вип. 39. С. 41-47.

10. Інноваційний розвиток підприємства : навч. посіб. / за ред. П.П. Микитюка. Тернопіль : ПП «Принтер Інсрорм», 2015. 224 C.

11. Маркетинг інновацій і інновації в маркетингу : монографрія / С.М. Ілляшенко [та ін.] ; заг. ред. С.М. Ілляшенка. Суми : Університетська книга, 2008. 615 с.

12. Бреус С. В. Роль інновацій у забезпеченні конкурентоспроможності машинобудівного комплексу України. Актуальні проблеми економіки. 2006. № 1. С. 162-169.

13. Бреус С.В., Шатненко Л.О. Стратегічне планування інноваційного розвитку промислового підприємства. Економіка і суспільство. 2018. Вип. 18. С. 292-301. DOI: https://doi.org/10.32782/2524-0072/2018-18-41

\section{REFERENCES:}

1. Duka, A.P. (2008) Teoriia ta praktyka investytsiinoi diialnosti [Theory and practice of investment activity]. Kyiv: Karavela. (in Ukrainian)

2. Illiashenko, S.M. (2003) Upravlinnia innovatsiinym rozvytkom: problemy, kontseptsii, metody [Management of innovative development: problems, concepts, methods]. Sumy: VTD «Universytetska knyha». (in Ukrainian)

3. Shumpeter, Y. (1982) Teoriya ekonomicheskogo razvitiya: Issledovanie predprinimatelskoy pribyili, kapitala, kredita, protsenta i tsikla kon'yunkturyi [Economic Development Theory: A Study of Entrepreneurial Profit, Capital, Credit, Interest, and the Business Cycle]. Moscow: Progress. (in Russian) 
4. Tuhan-Baranovskyi, M.I. (1994) Politychna ekonomiia. Kurs populiarnyi [Political Economy. The course is popular]. Kyiv: Naukova dumka. (in Ukrainian)

5. Kondratev, N.D. (1989) Problemyi ekonomicheskoy dinamiki [Problems of economic dynamics]. Moscow: Ekonomika. (in Russian)

6. Breus, S.V. \& Bondar, A.L. (2021) Upravlinnia innovatsiiamy u konteksti pidvyshchennia konkurentospromozhnosti subiekta hospodariuvannia [Innovation management in the context of increasing the competitiveness of business enterprise]. The VIII International Science Conference «Theoretical foundations of modern science and practice», November 08-10, Lisbon, Portugal, pp. 122-126. (in Ukrainian)

7. Pro innovatsiinu diialnist. Verkhovna Rada Ukrainy. Zakon vid 04.07.2002. Dokument 40-IV. Redaktsiia vid 05.12.2012, pidstava 5460-VI. Retrieved from: https://zakon.rada.gov.ua/laws/show/40-15\#Text

8. Peresada, A.A., Smirnova, O.O., Onikiienko, S.V. \& Liakhova, O.O. (2015) Investuvannia [Investment]. Kyiv: KNEU. (in Ukrainian)

9. Kukhta, P.V. \& Antoniuk, Ye.V. (2015) Analiz stanu finansovoho zabezpechennia innovatsiinoi diialnosti v Ukraini: suchasnyi stan ta osoblyvosti zrostannia [Analysis of innovation activity financing state in Ukraine]. Vcheni zapysky Universytetu «KROK» - Scientific Notes of «KROK» University, 39, 41-47.

10. Mykytiuk, P.P. (Ed.). (2015) Innovatsiinyi rozvytok pidpryiemstva [Innovative development of the enterprise]. Ternopil: PP «Prynter Inform». (in Ukrainian)

11. Illiashenko, S.M. et al. (Ed.) (2008) Marketynh innovatsii i innovatsii v marketynhu [Marketing innovation and innovation in marketing]. Sumy: Universytetska knyha. (in Ukrainian)

12. Breus, S.V. (2006) Rol innovatsii u zabezpechenni konkurentospromozhnosti mashynobudivnoho kompleksu Ukrainy [The role of innovations in ensuring the competitiveness of the machine-building complex of Ukraine]. Aktualni problemy ekonomiky - Actual Problems of Economics, 1, 162-169. (in Ukrainian)

13. Breus, S.V. \& Shatnenko, L.O. (2018) Stratehichne planuvannia innovatsiinoho rozvytku promyslovoho pidpryiemstva [Strategic planning of industrial enterprise's innovation development]. Ekonomika i suspilstvo - Economy and Society, 18, 292-301. DOI: https://doi.org/10.32782/2524-0072/2018-18-41 (in Ukrainian) 